\title{
A PROFILE OF THE SOCIO-DEMOGRAPHIC BACKGROUND OF CHILDREN ADMITTED WITH ACUTE DIARRHOEA TO THE RED CROSS CHILDREN'S HOSPITAL, CAPE TOWN
}

\author{
JM Huskisson and S Feulbach
}

\section{ABSTRACT}

The demographic and health profile and anthropometry of 106 young children hospitalised with acute diarrhoea during winter at the Red Cross War Memorial Children's Hospital, Cape Town, is reported.

Information regarding socio-economic status, feeding practices and mothers' knowledgetperceptions abott the aetlology of diarrhoea and the use of Oral Rehydration Therapy (ORT) was collected on a predetermined questionnaire in English or Xhosa.

The findings undertine the need for an aggressive, well-targeted education programume to reduce the morbidity and mortality of vulnerable children as well as the financial drain on the hospital budget.

\section{UITTREKSEL}

Die demografiese en gesondheidsprofiel, asook die antropometriese metings van 106 Jong kinders met akute diarree wat toegelaat is tot die Rooikruis Oorlogsgedenk-Hospital vir Kinders, word beskryf.

Inligting met betrekking tot sosio-ekonomiese status, voedingspraktyke en moeders se kennis/persepsie omtrent die oorsaak van diarree en die gebruik van Orale Rehidrasie Terapie, is verkry met behulp van $n$ vooraf bepaalde vraelys in Engels of Xhosa.

Die bevindings beklemtoon die behoefte aan $n$ aggressiewe, doelgerigte voorligtingsprogram om die morbiditeit en mortaliteit van kwesbare kinders te verlaag en terselfdertyd die finansiële druk op die hospitaalbegroting te verlig.

\section{INTRODUCTION}

The obvious impact of warm weather on the incidence of infective diarrhoea on young children is well-established. This study was undertaken during two winter months (July, August, 1993) to determine the demographic and nutritional factors which may influence this condition where climate does not play a significant role. The educational level. perceptions of diarrhoea and the understanding of Oral Rehydration Therapy (ORT) of the mothers (or child-minder) of young children, brought to Red Cross Children's Hospital, Cape Town were studied.

As $60-70 \%$ of deaths from diarthoea are caused by dehydration (WHO/UNICEF joint statement, 1983) a major objective of this study was to determine mothers'awareness of the hazards of diarrhoeal disease, their perception of the causes and understanding of the preparation of the oral rehydration formula. It is estimated that the correct implementation of ORT could prevent more than $90 \%$ of deaths associated with diarrhoea world-wide (Ferrinho, Gear, and Reinach, 1989).

\begin{tabular}{|c|c|c|c|}
\hline \multicolumn{4}{|c|}{ Table 1 Age range of children } \\
\hline Age -months- & No. of infants $(\%)$ & COLOUREDS & BLACKS \\
\hline $1 \cdot 3$ & $14(13.2)$ & 4 & 10 \\
\hline $4-6$ & $28(26.4)$ & 13 & 15 \\
\hline $7 \cdot 9$ & $23(21.7)$ & 7 & 16 \\
\hline $10 \cdot 12$ & $9(8.5)$ & 3 & 6 \\
\hline $13-15$ & $10(9.4)$ & 4 & 6 \\
\hline $16-18$ & $3(2.8)$ & 1 & 2 \\
\hline $19-21$ & $3(2.8)$ & 1 & 2 \\
\hline $22-24$ & $9(8.5)$ & 6 & 3 \\
\hline$>24$ & $7(6.6)$ & 3 & 4 \\
\hline
\end{tabular}

\section{PATIENTS AND METHODS}

One hundred and six consecutive patients aged six weeks to four years, who were admitted to the Red Cross Children's Hospital with acute infective diarrhoea and who met the required criteria were included in the study. The predetermined age-range was 6 months - 4 years and in view of the preponderance of Black and Coloured children attending this hospital, the two White children admitted in this group were excluded. There were 64 Black and 42 Coloured children included.

Children were excluded if the escort was unfamiliar with home circumstances, if the child was suffering from relevant organic disease or if reliable communication with the child-minders was impossible.

The mother (or in a single case, the child-minder), was interviewed in English by a senior dietetics student with the help of a trained Xhosa interpreter as required. Information regarding birth date, growth, immunisation status and nutritional history and status was collected on each child, both through questioning and from the folder. Interviews were conducted with all participants from a predetermined questionnaire consisting of predominantly open-ended questions.

The questionnaire was field-piloted before commencement of the study.

The U.S. National Centre for Health Statistics (NCHS) centiles were used as a reference standard. (Hamill, Drizol et al 1977). Data were processed using the Epi-Info software programme. 
Table II: NUTRITIONAL STATUS OF CHILDREN

Nutritional Status and Feeding Practices:

Below 5th percentile length for age, on admission.

\begin{tabular}{cr}
\multicolumn{2}{c}{$(N=106)$} \\
$\%$ & No \\
17,0 & 18
\end{tabular}

Malnutrition plus dehydration, on admission.

Below 5th percentile Weight for age:

On Admission:-

$23,6 \quad 25$

On Discharge:-

Severe episode of diarthoea previously

$25,5 \quad 27$

Continued feeding during diarthoeal episode.

$67,9 \quad 72$

\section{Table III: GROWTH CHARTS}

Road to Health Chart available

$(\mathrm{N}=106)$

Road to Health Chart available.

$57,5 \% \quad 61$

No Road to Health Chart.

$35 \% \quad 37$

$6.6 \%$

\section{Table IV : SOCIO-DEMOGRAPHIC CHARACTERISTICS}

A. General characteristics of child's family

Permanently resident in greater Cape Town:

Single mothers:

Supported by child's father

Employed:

Education: Primary school education:

High school education (to matric)

Size of families: 1 - 3 children

\begin{tabular}{rr}
\multicolumn{2}{c}{$(N=106)$} \\
$\%$ & No \\
91 & 96 \\
54,7 & 58 \\
35,8 & 38 \\
40 & 42 \\
84,0 & 89 \\
5,7 & 6 \\
87 & 92 \\
& \\
& \\
28,3 & 30 \\
52,8 & 56 \\
10,4 & 11
\end{tabular}

B. Housing:

Formal house, with services

Informal house, shack, no services

C. Water-supply:

Inside tap:

Outside tap:

Communal tap:

No running water:

D. Tollet:

Inside flush:

Outside flush

Communal flush:

Own bucket:

Communal buckevpit latrine

E. Cooking fuel:

Eloctricity:

Paraffin.

Gas

Coalwood

\section{RESULTS \& DISCUSSION}

Children:Nutritional Aspects:

a) Feeding practices were a source of grave concern. On admission 69\% (73) of children were predominantly bottle-fed. The association between termination of breast-feeding and malnutrition. lowered immunity and resultant diarrhoea has long been recognised (Chen, et al 1981). Twenty-six percent (28) of the sample commenced with bottle feeding before the infant was four weeks old. In the formula-fed group $40 \%$ (42) of the mothers had stopped breast-feeding due to their perception of insufficient milk and a further $20 \%$ (21) of the mothers informed the interviewer that "the baby did not like breast milk".

b) Seventy-five percent (80) of the children in the sample were fed solids before being offered the breast or formula. Whilst this practice may be quite acceptable in a First World environment where mothers can afford the ingredients for an appropriate supplementary meal and feed their children suitable quantities, it is clearly inadvisable in an impoverished community (Jelliffe 1985).

A considerable source of concern is thus the allaying of the child's hunger with large helpings of mealie-meal, often prepared several hours previously and which may become contaminated (Motarjemi et al 1971) and cause diarthoea as well as result in, considerably less milk being consumed at that meal. (Wittenberg and Loening 1989).

c) As found in the study by Nombe, (1992)) the recognition of the role of growth charts was poor: only $57,5 \%$ brought these records with them.

\section{Demugraphic Profile:}

Von Schirnding et al (1993: 78) state ...." infant mortality rate is directly proportional to the availability of toilet facilities, water supply points, the type of dwelling, and mother's education". Of particular interest in this present study was the number of subjects who had access to adequate water supply and sanitation - (Table IV C \& D).

The above study gives estimated figures for the entire R.S.A. Black \& "Coloured" population as $46 \%$ (adequate water supply) and $32 \%$ (adequate sanitation).

\section{Mothers:K nowledge and Attitudes:}

a) Mothers' knowledge of the preparation of formulae was poor. One third insisted they were given no information regarding preparation by the clinic staff, which must conoribute to the fact that 


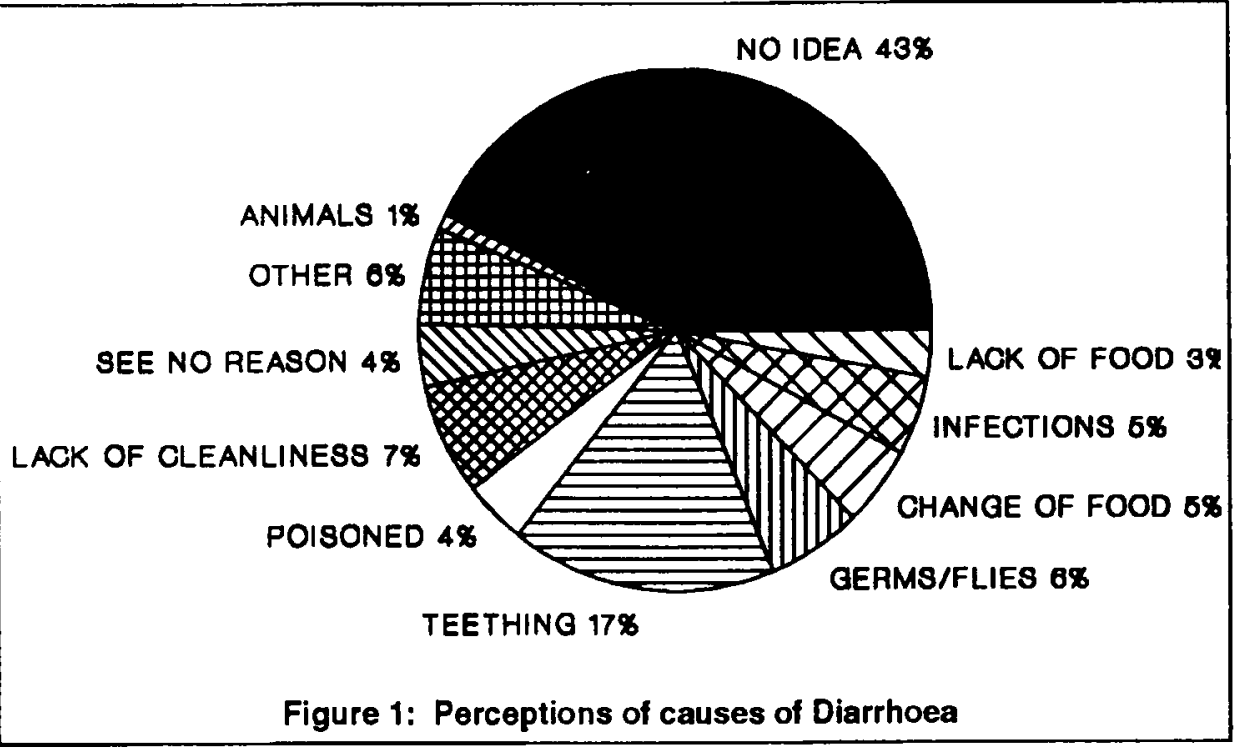

TABLE V: REASONS FOR BRINGING CHILD TO R.C.C.H.

REASONS FOR BRINGING CHILD TO R.C.C.H.

Expectations of better care

Sent directly by G.P

Local clinic closed.

No drip-room at local clinic

$48,2 \%$ prepared the formula incorrectly. From this study it was also clear that comprehension of information on formula labels is poor. The main reasons for this appeared to be the inability of Xhosa-literate mothers to read English or Afrikaans labels, misunderstanding of directions given and in some cases illiteracy. However, $68 \%$ continued feeding their children during their bout of diarrhoea, which suggests that some nutrition education is filtering through from clinics and health-workers.

In general there was a poor understanding of the causes of diarrhoea. Over $40 \%$ assumed that they had inadvertently caused it but had no idea of their error. Other perceptions of causes of diarrhoea are given in Fig. 1.

b) Having been taught on admission to Red Cross Hospital about ORT 78\% of the mothers were able to prepare the solution adequately. However, one third of the mothers had no understanding of the purpose of administration. Of the 71 mothers who claimed prior knowledge of the mixture, 9 had used it previously.

c) In view of the current Primary Health Care policy of the State Health Departments and intention that the exclusive use of tertiary institutions be for conditions requiring specialist care, it was deemed relevant to ascertain the reasons for mothers bringing their children to Red Cross Children's Hospital (RCCH) often at considerable cost - instead of their local clinics. Responses are given in Table V.
Furthermore, if the implementation of Primary Health Care is to be effective we will have to speak with one voice.

\section{REFERENCES:}

CHEN, C.C. HUG, E, HOFFMAN, S.L. (1981): A prospective study of the risk of diarrhoeal diseases according to the nutritional status of children. Am J. Epid. 114: $284-292$

CLEASON, M. and MERSON, M.H. (1990): Global progress in the control of diarrhoeal diseases. Ped. Infect. Dis.J. 9: 345

FERRINHO, P DE L.G.M., GEAR, J.S.S., REINACH, S.G. (1989): Diarrhoeal diseases and oral fluid therapy - the Gelukspan health ward. S.Afr. Med. J : $76,496-499$

HAMILL, P.V.V., DRIZD, T.A., JOHNSON, C.L., REED, R.B., ROCHE, A.F.: NCHS Growth Curves for Children Birth - 18 years, United States, DHEW Publ. No (PHS) 78 - 1650. Supt. of Documents, U.S. Government Printing Office, Washington, D.C. 1977.

JELLIFFE, D.B. (1985): Child Health in the Tropics. Oxford University Press. London.

MOTARJEMI,Y., KAFERSTEIN.F., MOY,G., QUEVEDO,F.: Contaminated weaning food. A major risk factor for diarrhoea and associated malnutrition. Bulletin WHO 71 (1): 79.87

NOMBE, E (1992): An investigation into the knowledge mothers have about children's growth charts. Curationis 15:26.

Current efforts promoting breast-feeding should be reinforced as well as appropriate weaning practices. The fact that three-quarters of the sample were fed solids (invariably cereal) before breast or formula feeding, clearly impacts on the nutritional status of the children.

If health educators are to promote self-reliance in managing diarrhoea at home, mothers need a consistent message regarding the standard recipe for ORT $(0,5$ teaspoonful salt, 1 litre water and 8 tablespoonfuls sugar) the frequency of administration (after every loose stool) and the quantity required to prevent dehydration (1 - 2 cups). Many mothers appear to regard ORT as a medicine to be administered by the teaspoonful at specific times of day (Cleason and Merson, 1990).

While there is no doubt that a well-targeted nutrition supplementation programme will go a long way in relieving the widespread malnutrition among the disadvantaged people in this country in the short-term, unless the distribution of food is accompanied by an extended nutrition education programme, there is little hope of long-term improvement in nutritional status.
WITTENBERG, D.F., LOENING, W.E., (1989); Diarrhoea is a nutritional disease S.Afr. Med. J. 76: 476 - 478.

WHO/UNICEF joint statement. The management of diarrhoea and the use of oral rehydration therapy. Geneva: WHO, 1983.

VON SCHIRDING, Y., YACH D., MATHEE A. (1993): Health Aspects of Sanitation with special reference to South Africa ChASA J., Compr. Health 4: 73 - 79

JOAN M HUSKISSON
B.Sc. (Hons) Dietetics (Stellenbosch)
Head of Department
Nutrition \& Dietetics Unit
OBSERVATORY
STEPHANIE FEULBACH
(Justus Liebig University
Giessen, Germany)
elective Dietetic student at the
Department of Medicine, Nutrition \&
Dietetics Unit, U.C.T.

